(RESEARCH ARTICLE)

\title{
An appraisal of antimicrobial, cytotoxic and phytotoxic potential of Oligomeris linifolia
}

\author{
Khuram Ashfaq $1{ }^{1,}$, Muhammad Tariq ${ }^{2}$, M Abuzar Ghaffari ${ }^{3}$ and Sajid N Hussain 3 \\ ${ }^{1}$ Department of pharmaceutical chemistry, Lahore Pharmacy College. \\ 2 Department of pharmacology, Lahore Pharmacy College, Tulspura, Lahore. \\ ${ }^{3}$ Faculty of pharmacy, B.Z.U. Multan.
}

Publication history: Received on 23 September 2020; revised on 06 October 2020; accepted on 10 October 2020

Article DOI: https://doi.org/10.30574/wjarr.2020.8.1.0355

\begin{abstract}
The aim of study was to evaluate the antimicrobial, cytotoxic and phytotoxic activities of the Oligomeris linifolia. The organic extracts were obtained by extraction the whole dried palnt with dichloromethane and methanol. The antibacterial activity was determined by inhibitory effect on the growth of Eschericha coli, Bacillus subtilis, Shigella flexinari, Staphylococcus aureus, Pseudomonas aeruginosa and Salmonella typhi by using Agar tube diffusion method. The antifungal potential of the extracts was determined against growth of Candida albicans, Aspergillus flavus, Microsporum canis, Fusarium solani, Candida glabrata .Cytotoxic activity was evaluated by brine shrimp lethality test and phytotoxic activity was conducted against growth of Lemna minor frond. The phytochemical screening led to the presence of cardiotonic glycosides, anthraquinones and saponins in the plant. Methanol extract exhibited substantial antibacterial activity against Pseudomonas aeruginosa. In antifungal bioassay, Methanol extract showed 50\% inhibition against Microsporum canis, while dichloromethane extract showed 40\% inhibition against Aspergillus flavus and Fusarium solani as compared to standard drug. The dichloromethane extract showed significant activity at highest dose while the methanol extract showed good activity at highest dose against Lemna minor in phytotoxic bioassay. In Brine shrimp lethality bioassay methanol extract showed significant cytotoxicity at highest level of dose with LD50 462.40.The study concluded that Oligomeris linifolia has noteworthy antimicrobial, phytotoxic and cytotoxic potential.
\end{abstract}

Keywords: Oligomeris linifolia; Phytochemical screening; Antimicrobial; Cytotoxic; Phytotoxic

\section{Introduction}

Pain, disease and death have always been associated with the human life. The men of early ages must have used therapeutical agents from those things which were easily available to them. Plants were among those things which have used as remedies since time immemorial [1]. Infectious diseases are the leading cause of death world-wide. Antibiotic resistance has become a global concern [2]. The clinical efficacy of many existing antibiotics is being threatened by the emergence of multidrug-resistant pathogens [3]. Many infectious diseases have been known to be treated with herbal remedies throughout the history of mankind. Natural products, either as pure compounds or as standardized plant extracts, provide unlimited opportunities for new drug leads because of the unmatched availability of chemical diversity. There is a continuous and urgent need to discover new antimicrobial compounds with diverse chemical structures and novel mechanisms of action for new and re-emerging infectious diseases [4]. Therefore, researchers are increasingly turning their attention to folk medicine, looking for new leads to develop better drugs against microbial infections [5].

\footnotetext{
${ }^{*}$ Corresponding author: Khuram Ashfaq

Department of pharmaceutical chemistry, Lahore Pharmacy College

Copyright (@ 2020 Author(s) retain the copyright of this article. This article is published under the terms of the Creative Commons Attribution Liscense 4.0.
} 
The increasing recognition and importance of fungal infections, the difficulties encountered in their treatment and the increase in resistance to antifungals have stimulated the search for therapeutic alternatives. Microsporum canis causes Granuloma and Pseudogranuloma of the Skin which can be life threatening specially in patients with HIV infection. It also causes Tinea capitis and Pseudomycetoma [6]. Fusarium solani can cause mycotoxicosis, onychomycosis, septic arthritis, endophthalmitis, osteomyelitis and cystitis [7].

The brine shrimp lethality bioassay is widely used in the evaluation of toxicity of heavy metals, pesticides, medicines especially natural plant extracts and etc. It's a preliminary toxicity screen for further experiments on mammalian animal models [8].

Resedaceae is family of 6 genera and 70 species found mostly in dry habitats in Africa, S. Europe, Middle Eeast, Central Asia to SE. Asia and Eastern U.S.A". Oligomeris genus is with nine species distributed in SW. USA, N. \& S.Africa, Middle East to Pakistan and India. Represented locally by 1 species only [9].

Oligomeris linifolia (Vahl) (Rasedaceae) is one of four Oligomeris species, commonly named as lineleaf whitepuff. It is native to some parts of the Middle East India, Southern Europe, North Africa and North America. The plant grows in many habitat types including deserts, saline soils, plains, coastline, and other places. It is an annual herb, up to $50 \mathrm{~cm}$ tall, with a linear leaves and white flowers. [10].

\section{Material and methods}

The research work was carried out in natural product chemistry laboratory, Department of Pharmacy, Bahauddin Zakariya University, Multan. Description of materials and methods adopted is described below.

\subsection{Collection of Oligomeris linifolia}

The plant, Oligomeris linifolia wae collected from forest park of Perrowal distric Khanewal . Dr. Altaf Hussain Dasti (Professor, Institute of pure and applied Biology, Bahauddin Zakariya University, Multan) identified the plant as Oligomeris linifolia. The specimen voucher \# 38FCV1 was deposited in the herbarium of institute of pure and applied biology, Bahauddin Zakariya University, Multan.

\subsection{Extraction of Oligomeris linifolia}

For effective extraction of plant, whole plant material was kept under shade for drying for 15 days. When plant material dried, it was ground in grinding mill and weighed. The extraction of Oligomeris linifolia was carried out by simple maceration process. 350gm of ground plant material was taken in extraction bottle and measured volume of dichloromethane was added to it. To achieve maximum possible extraction, this mixture was shaken after some time then homogenized in ultrasonic bath. Filtration of this mixture was carried out after 24 hours. Then marc was macerated again by dichloromethane using same above procedure. After $3^{\text {rd }}$ collection of this extract, the marc was extracted by methanol in the same manner. The extracts of dichloromethane and methanol were concentrated separately under reduced pressure by using rotary evaporator. The extracts of dichloromethane and methanol were collected in separate sample bottles and weighed. Then they were designated codes as OLD and OLM respectively.

\subsection{Preliminary phytochemical analysis}

Chemical tests are used for evaluation and identification of constituents in drug sample. These tests are very specific for a single compound or general for a specific class of constituents i.e. alkaloids. Color or turbidity is developed in many tests. Color should be matched with an authentic specimen while turbidity in sample tube, in case of precipitation reactions, is compared with reagent containing test tube alone. Mostly, these tests can equally be applied for extracts and isolated components [11].

\subsubsection{Tests for cardiac glycosides (Keller Kiliani test)}

$1 \mathrm{~g}$ of ground drug under study was taken in test tube and $10 \mathrm{ml}$ of $70 \%$ alcohol was added to it. Then mixture was boiled for 2 minutes on water-bath and filtered. Filtrate was diluted with double volume of distilled water and strong solution of lead sub acetate was added. Solution was filtered again that remove chlorophyll and other pigments. The filtrate was extracted with $10 \mathrm{ml}$ of chloroform or carbon tetrachloride after shaking it vigorously. Chloroform layer was separated and evaporated to dryness in a china dish over water bath. The residue was dissolved in $3 \mathrm{ml}$ of $3.5 \%$ ferric chloride in acetic acid glacial and transferred to test tube after one minute. Then sulfuric acid was added carefully along the wall of test tube which formed the lower layer. Cardiac glycosides were confirmed by appearing of pale green color at upper layer (due to steroidal nucleus) and Brown color at interface (due to deoxy sugar) on standing [12]. 


\subsubsection{Test for anthraquinones glycosides (Borntrager's test)}

$0.5 \mathrm{~g}$ of ground drug on study was taken and extracted with $10 \mathrm{ml}$ of hot water for 5 minutes. It was filtered while hot, allowed to cool and extracted with $10 \mathrm{ml}$ of carbon tetrachloride. The carbon tetrachloride was taken off, washed with $5 \mathrm{ml}$ of water and shaken with $5 \mathrm{ml}$ of dilute ammonia solution. No free anthraquinones were revealed as absence of color (pink to cherry-red). $0.1 \mathrm{~g}$ of other powdered drug was extracted with $10 \mathrm{ml}$ of ferric chloride solution and $5 \mathrm{ml}$ hydrochloric acid. It was heated on water bath for 10 minutes and filtered hot solution, then cool the filtrate and subsequently extracted with $10 \mathrm{ml}$ of carbon tetrachloride. The carbon tetrachloride was taken off, washed with $5 \mathrm{ml}$ of water and shaken with $5 \mathrm{ml}$ of dilute ammonia solution. No anthraquinone glycosides were revealed as absence of color (intense pink to cherry-red) in drug under study [13].

\subsubsection{Tests for saponin glycosides}

$0.5 \mathrm{~g}$ of powdered drug was added to water. Persistent froth were formed which indicated presence of saponins [14].

\subsubsection{Tests for alkaloids}

$3 \mathrm{~g}$ of powdered drug under study was taken and boiled with $10 \mathrm{ml}$ of dilute $\mathrm{HCl}$ in a test tube for 1 minute then cool and allow the debris to settle. Supernatant liquid was poured off other test tube.3 drops of Dragendorff's reagent were added to $1 \mathrm{ml}$ of filtrate. The distinct precipitate or turbidity appeared that indicate presence of alkaloids. To further confirm the presence of alkaloids, the remainder of the filtrate was made alkaline to litmus paper with dilute ammonia solution. This alkalinized solution was transferred to separating funnel and extracted with $5 \mathrm{ml}$ of chloroform by shaking it gently. Two layers were observed. The lower chloroform layer was extracted with $10 \mathrm{ml}$ of dilute acetic acid and discarded the chloroform. The extract was divided into four portions and adds few drops of Wagner's reagent, Mayer's reagent and Dragendorff's reagent to three portions separately. An observation of turbidity or precipitate compared with untreated control (fourth portion) with either or all reagents confirmed presence of alkaloids [15].

\subsection{Biological screening}

\subsubsection{Antifungal assays}

Agar tube dilution assay was used for evaluation of antifungal assay. Stock solutions of dichloromethane and methanol extracts of plant (Oligomeris linifolia) were dissolved separately into sterile Dimethyl sulfoxide. By mixig Sabouraud 4 $\%$ glucose agar and agar in distilled water, Sabouraud dextrose agar was prepared and then it was stirred with a magnetic stirrer to dissolve it and a known amount of this agar was dispensed into a screw capped test tubes. Media containing test tubes were autoclaved at $121^{\circ} \mathrm{C}$ for $15 \mathrm{~min}$. Test tubes were cooled at $50^{\circ} \mathrm{C}$ and then test sample of required concentrations was pipetted from the stock solution into the non solidified Sabouraud agar media. At room temperature, tubes were solidified in a slanting position. Each of the tube was inoculated with inoculum of $4 \mathrm{~mm}$ diameter that was removed from seven days old culture of fungus. All tubes containing culture were inoculated for growth for 7-10 days at temperature of $28-30^{\circ}$ C. Humidity (40\%-50\%) was maintained in the incubator. Cultures were examined two times in a week during the incubation period. After the incubation period of 7-10 days, test tube of no any visible growth of the microorganisms was taken to represent the MIC of the test sample that was expressed in $\mu \mathrm{g} / \mathrm{ml}$ [16].

\subsubsection{Brine-Shrimp Lethality Assay}

Bioactive compounds cause toxicity to shrimp larvae. Thus, in vivo lethality to shrimp larvae is a simple and quick method for bioactive compounds. Eggs of brine shrimp (Leach) are available easily in pet shops. Large numbers of larvae are obtained by placing these eggs of brine shrimp which are hatched within 48 hours in artificial sea water and are used to measure cytotoxicity of test samples. The Brine-Shrimp lethality bioassay is a quick, economical and in house method for screening, fractionation and monitoring of physiologically active natural products [17]. Procedure: Artificial sea water was prepared by dissolving $3.8 \mathrm{~g}$ of sea salt/liter in water and filtered. Tanks were filled with artificial sea water and shrimp eggs that darkened by aluminum foil were added to the large compartment of tank. The shrimp larvae (nauplii) were attracted through illuminated compartment, then hatched the shrimp eggs and mature within two days at $22-29^{\circ} \mathrm{C}$. Testing vials were prepared for each fraction, that was tested initially at $1000,100 \mathrm{and} 10 \mu \mathrm{g} / \mathrm{ml}$. Then three replicates of each fraction were prepared and weighed $20 \mathrm{mg}$ of sample and $2 \mathrm{ml}$ of organic solvent $(20 \mathrm{mg} / 2 \mathrm{ml}) ;$ from this solution was transferred to $500 \mu \mathrm{l}, 50 \mu \mathrm{l}$ or $5 \mu \mathrm{l}$ vials corresponding to $1000,100 \mathrm{or} 10 \mu \mathrm{l} / \mathrm{ml} \mathrm{respectively}$. Then solvent was allowed to evaporate volatile organic solvent in overnight under nitrogen and placed in a high vacuum for $30 \mathrm{~min}$. Polar insoluble material was dissolved in dimethyl sulfoxide (DMSO) and up to $50 \mu \mathrm{l} / 5 \mathrm{ml}$ of artificial sea water was added before dimethyl sulfoxide toxicity. After two days of maturation of brine shrimp larvae; $5 \mathrm{ml}$ artificial sea water and ten shrimps for each vial with the help of Pasteur pipette ( 30 shrimps per dilution) was added. The vials were placed under illumination. After 24 hours, the number of surviving shrimps were counted and recorded with the help 
of a 3x magnifying glass. The Data was analyzed with Finney computer program (Probit analysis) to determine LC50 values and 95\% confidence intervals. Additional dilutions of less than $10 \mu \mathrm{g} / \mathrm{ml}$ were needed for potent materials. Intermediate concentrations prepared and tested to narrow the confidence interval.

\section{Results and discussion}

\subsection{Phytochemical screening of Oligomeris linifolia}

Detection of secondary metabolites e.g. alkaloids, anthraquinones (both free and bound forms), cardiac glycosides and saponins was carried out as per procedure described in Material and Method. The detection of alkaloids was performed by using Dragendorff's reagent, Mayer's reagent and Wagner's reagent. For the detection of free and bound anthraquinones Borntrager's test was performed. For the detection of cardiac glycosides Keller Kiliani test was performed. Froth test was employed for the detection of saponins. The results of detection of secondary metabolites in dichloromethane and methanol extracts of whole plant of Oligomeris linifolia are shown in table below 1.

Table 1 Results of detection of secondary metabolites in whole plant of Oligomeris linifolia.

\begin{tabular}{|l|l|l|l|l|}
\hline Plant Name & Alkaloids & Anthraquinones & Cardiac glycosides & Saponins \\
\hline Oligomeris linifolia & Absent & Present & Present & Present \\
\hline
\end{tabular}

\subsection{In vitro antibacterial bioassay}

Sample of both extracts were tested against Eschericha coli, Bacillus subtilis, Shigella flexinari, Staphylococcus aureus, Pseudomonas aeruginosa and Salmonella typhi by using Agar tube diffusion method. Bacillus subtilis is associated with bacteremia/septicemia, endocarditis, meningitis, and infections of wounds, the ears, eyes, respiratory tract, urinary tract, and gastrointestinal tract. Pseudomonas aeruginosa has become an important cause of gram-negative infection, especially in patients with compromised host defense mechanisms. It is the most common pathogen isolated from patients who have been hospitalized longer than 1 week, and it is a frequent cause of nosocomial infections. Pseudomonal infections are complicated and can be life-threatening. [18]. DCM extract showed moderate activity against Bacillus subtilis, where as methanol extract exhibited substantial activity against Pseudomonas aeruginosa Results are shown below in table 2 .

Table 2 Results of In vitro antibacterial bioassay of dichloromethane and methanol extract of Oligomeris linifolia.

\begin{tabular}{|l|l|l|l|}
\hline \multirow{4}{*}{ DCM extract } & Name of bacteria & $\begin{array}{l}\text { Zone of inhibition of } \\
\text { sample (mm) }\end{array}$ & $\begin{array}{l}\text { Zone of inhibition on } \\
\text { standard drug (mm) }\end{array}$ \\
\hline & Eschericha coli & - & 25 \\
\cline { 2 - 4 } & Bacillus subtilis & 24 & 50 \\
\cline { 2 - 4 } & Shigella flexinari & - & 28 \\
\cline { 2 - 4 } & Staphylococcus aureus & 10 & 48 \\
\cline { 2 - 4 } & Pseudomonas aeruginosa & - & 23 \\
\cline { 2 - 4 } & Salmonella typhi & - & 28 \\
\hline \multirow{5}{*}{ MeOH extract } & - & 25 \\
\cline { 2 - 4 } & Eschericha coli & 13 & 50 \\
\cline { 2 - 4 } & Bacillus subtilis & - & 28 \\
\cline { 2 - 4 } & Shigella flexinari & - & 28 \\
\cline { 2 - 4 } & Ptaphylococcus aureus & 17 & 28 \\
\cline { 2 - 4 } & Salmondomonas aeruginosa & - & 28 \\
\hline
\end{tabular}

\subsection{In vitro antifungal bioassay}

Fungal infections are common throughout much of the natural world. In humans, fungal infections occur when an invading fungus takes over an area of the body and is too much for the immune system to handle. 
Fungi can live in the air, soil, water, and plants. There are also some fungi that live naturally in the human body. Like many microbes, there are helpful fungi and harmful fungi. When harmful fungi invade the body, they can be difficult to kill, as they can survive in the environment and re-infect the person trying to get better.

A dramatic increase in the incidence of $M$. canis infection has been observed recently, both in absolute figures and as compared to the rest of isolated dermatophytes. M. canis is a cause of tinea most prevalent in children. M. canis infection is becoming a serious epidemiologic problem in Europe and Asia. [19].

The methanol and dichloromethane extracts of Oligomeris linifolia showed non-significant activity against Candida albicans, Aspergillus flavus, Microsporum canis, Fusarium solani, Candida glabrata. It has been noted that MeOH extract showed 50\% inhibition with linear growth at $80 \mathrm{~mm}$, when compared with control; only against Microsporum canis, while dichloromethane extract showed $40 \%$ inhibition with linear growth at $80 \mathrm{~mm}$, when compared with control, against Aspergillus flavus and Fusarium solani. In vitro antifungal bioassay was performed by following Agar tube dilution protocol. Results are shown below in table 3.

Table 3 Results of In vitro antifungal bioassay of dichloromethane and methanol extract of Oligomeris linifolia.

\begin{tabular}{|c|c|c|c|c|c|c|}
\hline \multirow{2}{*}{ Extract } & \multirow{2}{*}{$\begin{array}{l}\text { Name of } \\
\text { Fungus }\end{array}$} & \multicolumn{2}{|c|}{ Linear Growth (mm) } & \multirow{2}{*}{ \% Inhibition } & \multirow{2}{*}{ Standard Drug } & \multirow{2}{*}{$\begin{array}{l}\mathrm{Mic} \\
(\mu \mathrm{g} / \mathrm{ml})\end{array}$} \\
\hline & & Sample & Control & & & \\
\hline \multirow{5}{*}{ DCM } & $\begin{array}{l}\text { Candida } \\
\text { albicans }\end{array}$ & 100 & 100 & 0 & Miconazole & 110.8 \\
\hline & $\begin{array}{l}\text { Aspergillus } \\
\text { flavus }\end{array}$ & 60 & 100 & 40 & Amphotericin B & 20.20 \\
\hline & $\begin{array}{l}\text { Microsporum } \\
\text { canis }\end{array}$ & 100 & 100 & 0 & Miconazole & 98.4 \\
\hline & $\begin{array}{l}\text { Fusarium } \\
\text { solani }\end{array}$ & 60 & 100 & 40 & Miconazole & 73.25 \\
\hline & $\begin{array}{l}\text { Candida } \\
\text { glabrata }\end{array}$ & 100 & 100 & 0 & Miconazole & 110.8 \\
\hline \multirow{5}{*}{$\mathrm{MeOH}$} & $\begin{array}{l}\text { Candida } \\
\text { albicans }\end{array}$ & 100 & 100 & 0 & Miconazole & 110.8 \\
\hline & $\begin{array}{l}\text { Aspergillus } \\
\text { flavus }\end{array}$ & 100 & 100 & 0 & Amphotericin B & 20.20 \\
\hline & $\begin{array}{l}\text { Microsporum } \\
\text { canis }\end{array}$ & 50 & 100 & 50 & Miconazole & 98.4 \\
\hline & $\begin{array}{l}\text { Fusarium } \\
\text { solani }\end{array}$ & 100 & 100 & 0 & Miconazole & 73.25 \\
\hline & $\begin{array}{l}\text { Candida } \\
\text { glabrata }\end{array}$ & 100 & 100 & 0 & Miconazole & 110.8 \\
\hline
\end{tabular}

\subsection{In vitro phytotoxic bioassay}

Overuse of synthetic herbicides to control weeds lead to an increased risk of herbicide resistant weed biotypes and harsh environmental pollutions. Alternative weed management strategies that are ecofriendly and cost-effective are therefore a time demanding issue throughout the world. In this backdrop, phytotoxic plants might help in resolving the problems created by synthetic herbicides as they possess growth retarding substances. Recently, there has been an increasing interest shown by the researchers on phytotoxic medicinal plants [20].

The methanol and dichloromethane extracts of Oligomeris linifolia were tested for their phytotoxic potential by performing In vitro phytotoxic bioassay against Lemna minor. The dichloromethane extract showed significant activity just at highest dose while the methanol extract showed good activity at highest dose. Results are shown below in table 4. 
Table 4 Results of In vitro phytotoxic bioassay of dichloromethane and methanol extract of Oligomeris linifolia.

\begin{tabular}{|c|c|c|c|c|c|c|}
\hline \multirow{2}{*}{ Extract } & \multirow{2}{*}{ Plant Name } & \multirow{2}{*}{$\begin{array}{l}\text { Conc. of } \\
\text { Compound } \\
(\mu \mathrm{g} / \mathrm{ml})\end{array}$} & \multicolumn{2}{|c|}{ No. of Fronds } & \multirow{2}{*}{$\begin{array}{l}\text { \% Growth } \\
\text { Regulation }\end{array}$} & \multirow{2}{*}{$\begin{array}{l}\text { Conc. of Standard } \\
\text { Drug(paraquat) } \\
(\mu \mathrm{g} / \mathrm{ml})\end{array}$} \\
\hline & & & Sample & Control & & \\
\hline \multirow{3}{*}{ DCM } & \multirow{6}{*}{$\begin{array}{l}\text { Lemna } \\
\text { minor }\end{array}$} & 1000 & 05 & \multirow{3}{*}{20} & 75 & \multirow{6}{*}{0.015} \\
\hline & & 100 & 18 & & 10 & \\
\hline & & 10 & 19 & & 5 & \\
\hline \multirow{3}{*}{$\mathrm{MeOH}$} & & 1000 & 09 & \multirow{3}{*}{20} & 55 & \\
\hline & & 100 & 13 & & 35 & \\
\hline & & 10 & 19 & & 05 & \\
\hline
\end{tabular}

\subsection{Brine shrimp (Artemia salina) lethality bioassay}

The brine shrimp lethality assay represents a rapid, inexpensive and simple bioassay for testing plant extracts bioactivity which in most cases correlates reasonably well with cytotoxic and anti-tumor properties [21]. The dichloromethane and methanol extracts of Oligomeris linifolia were tested for their cytotoxic potential by performing Brine shrimp (Artemia salina) lethality bioassay. The dichloromethane extract showed no cytotoxicity while methanol extracts demonstrated cytotoxicity at highest level of dose with LD 50 462.40. Results are shown below in table below 5 .

Table 5 Results of Brine shrimp (Artemia salina) lethality bioassay of dichloromethane and methanol extract of Oligomeris linifolia.

\begin{tabular}{|l|l|l|l|l|l|l|}
\hline \multirow{3}{*}{ Extract } & Dose $(\boldsymbol{\mu g} / \mathbf{m l})$ & No. of shrimps & No. of survivors & LD50 $(\boldsymbol{\mu g} / \mathbf{m l})$ & STD. Drug & LD50 ( $\boldsymbol{\mu g} / \mathbf{m l})$ \\
\hline \multirow{3}{*}{ MEOH } & 1000 & 30 & 24 & \multirow{2}{*}{45456.4} & \multirow{2}{*}{ Etoposide } & \multirow{2}{*}{7.4625} \\
\cline { 2 - 4 } & 100 & 30 & 28 & & \\
\cline { 2 - 4 } & 10 & 30 & 29 & \multirow{2}{*}{462.4} & \multirow{2}{*}{ Etoposide 7.4625} \\
\cline { 2 - 4 } & 1000 & 30 & 02 & & \\
\end{tabular}

\section{Conclusion}

The result of the present study revealed that the methanol extract of Oligomeris linifolia has significant antibacterial action against Pseudomonas aeruginosa. Moderate antifungal potential was exhibited by both plant extracts. Study also revealed phytotoxic and cytotoxic potential of investigated plant. Further investigation is suggested for isolation of secondary metabolites accountable for observed activities.

\section{Compliance with ethical standards}

\section{Ack nowledgments}

We are thankful to department of pharmaceutical chemistry, Bahaudin Zakariya University, for providing laboratory facility.

\section{Disclosure of conflict of interest}

The authors have no conflict of interests. 


\section{References}

[1] Kappos AD, Bruckmann P, Eikmann T, Englert N, Heinrich U, Höppe P, Koch E, Krause GH, Kreyling WG, Rauchfuss $\mathrm{K}$, Rombout P. Health effects of particles in ambient air. International journal of hygiene and environmental health. 1sep 2004; 207(4): 399-407.

[2] Westh H, Zinn CS, Rosdahl VT, Sarisa Study Group. An international multicenter study of antimicrobial consumption and resistance in Staphylococcus aureus isolates from 15 hospitals in 14 countries. Microbial drug resistance. 1 jun 2004; 10(2): 169-76.

[3] Bandow JE, Brötz H, Leichert LI, Labischinski H, Hecker M. Proteomic approach to understanding antibiotic action. Antimicrobial agents and chemotherapy. 1 Mar 2003; 47(3): 948-55.

[4] Rojas R, Bustamante B, Bauer J, Fernández I, Albán J, Lock O. Antimicrobial activity of selected Peruvian medicinal plants. Journal of ethnopharmacology. 1 Oct 2003; 88(2-3): 199-204.

[5] Oladele AC, Olumayowa AA, Temitope OS. Phytochemical and antimicrobial activity of ethnomedicinal leaf extract of selected plants in Nigeria. World Journal of Advanced Research and Reviews. 2020; 7(1): 253-62.

[6] Barson WJ. Granuloma and pseudogranuloma of the skin due to Microsporum canis: successful management with local injections of miconazole. Archives of dermatology. 1 Jul 1985; 121(7): 895-7.

[7] Gupta AK, Baran R, Summerbell RC. Fusarium infections of the skin. Current opinion in infectious diseases. 1 Apr 2000; 13(2): 121-8.

[8] Ramachandran S, Vamsikrishna M, Gowthami KV, Heera B, Dhanaraju MD. Assessment of cytotoxic activity of Agave cantula using brine shrimp (Artemia salina) lethality bioassay. Asian Journal of Scientific Research. 2011; 4(1): 90-4.

[9] Ali SI. Papilionaceae In: Flora of Pakistan.(Eds.): E. Nasir \& SI Ali. 1977; (100).

[10] El-Hagrassy AM, Elkhateeb A, Hussein SR, Abdel-Hameed ES, Marzouk MM. LC-ESI-MS profile, antioxidant activity and cytotoxic screening of Oligomeris linifolia (Vahl) Macbr.(Resedaceae). Journal of Applied Pharmaceutical Science. Aug 2017; 7(8): 43-7.

[11] Musa KY, Katsayal AU, Ahmed A, Mohammed Z, Danmalam UH. Pharmacognostic investigation of the leaves of Gisekia pharnacioides. African Journal of Biotechnology. 2006; 5(10).

[12] Abdullahi MN, Ilyas N, Ibrahim H. Evaluation of phytochemical screening and analgesic activity of aqueous extract of the leaves of Microtrichia perotitii Dc (Asteraceae) in mice using hotplate method. Medicinal Plant Research. 21 Mar 2013; 3(5).

[13] De S, Dey YN, Ghosh AK. Phytochemical investigation and chromatographic evaluation of the different extracts of tuber of Amorphaphallus paeoniifolius (Araceae). Int J Pharm Biol Res. 2010; 1(5): 150-7.

[14] Zahro L, Agustini R. Uji Efektivitas Antibakteri Ekstrak Kasar Saponin Jamur Tiram Putih (Pleurotus Ostreatus) Terhadap Staphylococcus Aureus Dan Escherichia Coli Antibacterial Effectivity Test Of Saponins Crude Extract From White Oyster Mushroom (Pleurotus Ostreatus) Against. UNESA Journal of Chemistry. 25 Sep 2013; 2(3).

[15] Hussain HS, Deeni YY. Plants in Kano ethnomedicine; screening for antimicrobial activity and alkaloids. International Journal of Pharmacognosy. 1 Jan 1991; 29(1): 51-6.

[16] Irobi ON, Daramola SO. Antifungal activities of crude extracts of Mitracarpus villosus (Rubiaceae). Journal of ethnopharmacology. 1 Oct 1993; 40(2): 137-40.

[17] Meyer BN, Ferrigni NR, Putnam JE, Jacobsen LB, Nichols DJ, McLaughlin JL. Brine shrimp: a convenient general bioassay for active plant constituents. Planta medica. May 1982; 45(05): 31-4.

[18] Lau GW, Hassett DJ, Ran H, Kong F. The role of pyocyanin in Pseudomonas aeruginosa infection. Trends in molecular medicine. 1 Dec 2004; 10(12): 599-606.

[19] Lunder M. Is Microsporum canis infection about to become a serious dermatological problem?. Dermatology. 1992; 184(2): 87-9.

[20] Islam AK, Kato-Noguchi H. Phytotoxic activity of Ocimum tenuiflorum extracts on germination and seedling growth of different plant species. The Scientific World Journal. Jul 2014.

[21] Krishnaraju AV, Rao TV, Sundararaju D, Vanisree M, Tsay HS, Subbaraju GV. Assessment of bioactivity of Indian medicinal plants using brine shrimp (Artemia salina) lethality assay. Int J Appl Sci Eng. 1 Oct 2005; 3(2): 125-34. 